\title{
PERLAKUAN AKUNTANSI TERHADAP PRODUK RUSAK DAN PENGARUHNYA TERHADAP HARGA POKOK PRODUKSI PADA PT JATIM TAMAN STEEL, MFG SIDOARJO.
}

\author{
Dewi Mashita Indah Pratiwi ${ }^{1}$, Subakir \\ Universitas PGRI Adi Buana Surabaya ${ }^{1,2}$ \\ aku.dewishita@gmail.com¹ \\ subakir.unipasby@gmail.com²
}

\begin{abstract}
In the business world, business people are required to produce good quality products to be able to compete with competitors. However, in the process, the production process does not always get good products, sometimes it gets damaged products in every process. There are 2 categories of damaged products requested by the company, namely damaged products that can be resold and also damaged products that cannot be sold anymore. The purpose of conducting this research analysis is to determine the effect of the accounting treatment of damaged products in the calculation of the cost of production. The accounting treatment of damaged products in PT Jatim Taman Steel, MFG Sidoarjo in fact is not in accordance with existing theoretical analysis, in the product price report in the production report section, damaged products that occur annually are included in the final product that is there every year, according to theoretical studies Damaged products are still treated as damaged products instead of being put into finished products. Some theories explain if the cost of goods reported, the cost of damaged goods is charged to the final product which results in higher cost of the final product per unit.
\end{abstract}

\section{Keyword :Accounting Treatment, Damaged Products, HPP}

\section{PENDAHULUAN}

Dalam era digital saat ini system informasi telah mengalami kemajuan yang sangat pesat, dampaknya adalah banyak persaingan bisnis bebas dalam segala aspek kehidupan.Para pelaku bisnis yang menginginkan pendapatan (laba) yang besar setidaknya memiliki daya saing kuat untuk menyaingi para kompetitornya. Setiap barang jadi (produk siap jual) yang telah lolos proses produksi harus memiliki kualitas yang baik dan disertai dengan harga yang bersaing. Salah satu tahap yang paling berpengaruh adalah proses produksi, disini proses produksi menjadi penentu tentang kualitas dan kwantitas produk yang dihasilkan.

Dalam melakukan proses produksi diperlukan beberapa elemen produksi seperti kebutuhan tenaga kerja langsung, tersedianya bahan baku, dan biaya overhead pabrik, dan juga perlunya beberapa bahan penolong yang dibutuhkan untuk menunjang pelaksanaan produksi. Dalam pelaksanaannya, proses produksi setidaknya mengalami penyimpangan dari rencana awal yang telah disusun oleh perusahaan sebelumnya, karena dalam prosesnya tidak semua produk jadi yang dihasilkan dalam proses produksi adalah produk dalam kategori baik dan juga telah memenuhi standar kelayakan yang telah ditentukan perusahaan. Ketidak sempurnaan hasil produksi dalam suatu produk dapat di kategorikan kedalam produk rusak.

Didalam perusahaan produk rusak memiliki 2 jenis yakni produk rusak yang masih bisa dijual dan juga produk rusak yang tidak bisa dijual kembali . Secara umum produk yang dikategorikan kedalam produk rusak ialah sebuah barang yang telah sampai pada proses akhir produksi namun produk ini tidak memenuhi standar kualitas 
Journal of Sustainability Business Research (JSBR)

Vol-1,Issue-1,Desember (JSBR)

\section{E-ISSN: 2746-8607}

http://jurnal.unipasby.ac.id/index.php/jsbr

yang telah ada diperusahaan, secara ekonomis produk ini tidakakan dilakukan perbaikan lagi dan dinyatakan telah rusak. Produk rusak yang telah dihasilkan akan menjadi salah satu pengaruh negatif terhadap manajemen laba (keuntungan) yang akan di dapat oleh perusahaan tersebut. Terjadinya hal ini menyebabkan produk tersebut dinyatakan tidak bisa untuk dijual lagi dengan harga yang diberikan oleh perusahaan, karena itu memerlukan paham lebih lanjut untuk mendalami perlakuan akuntansi yang tepat dan sesuai dengan kondisi perusahaan. Perusahaan ini menganut sistem akuntansi yang menekankan terhadap elemen-elemen biaya yang bisa digunakan untuk menentukan harga yang nantinya akan timbul karena produk rusak.

Akuntansi biaya merupakan proses pencatatan, penggolongan dan peringkasan dan penyajian biaya pembuatan dan penjualan produk jasa dengan cara tertentu serta bentuk penafsiran terhadapnya (Mulyadi, 2015). Akuntansi biaya juga berisi tentang informasi biaya produksi untuk kepentingan kegiatan manajemen perusahaan industri, yang meliputi adanya bahan baku, biaya tenaga kerjalangsung, dan biaya overhead pabrik, penyimpanan, dan penjualan produk jadi (Sujarweni, 2015)

Dengan hal ini perusahaan dituntut harus tepat, dalam menetapkan harga untuk menjual kembali produk yang telah mengalami kecacatan, (produk yang tidak sempurna seperti mengalami kecacatan fisik, kondisi penyok, ukuran tidaksesuai, produk mengalami kerosi), sehingga harga jual pada produk tersebut termasuk kedalam harga rata-rata yakni sebanding dengan harga produk rusak yang beredar dipasaran, untuk harga reatif terjangkau. Ketika perusahaan menginginkan harga jual yang lebih tinggi daripada harga yang ditawarkan dipasar maka hal ini akan secara langsung mempengaruhi volume penjualan, dan disini mengakibatkan volume penjualan menjadi turun dikarenakan para calon pembeli tidak mampu membeli barang /produk yang telah ditawarkan oleh perusahaan, dan hal terburuknya adalah konsumen memilih untuk membeli produk yang sama di perusahaan competitor lain karena perusahaan lain menawarkan barang yang sama dengan harga relatif terjangkau. Hal ini akan mempengaruhi manajemen laba yang dihasilkan oleh perusahaan tersebut. Penurunan manajemen laba akan segera terjadi karena produk tersebut dinyatakan tidak bisa dijual kembali dengan harga baru oleh perusahaan, perusahaan memerlukan beberapa paham atas perlakuan akuntansi yang baik dan sesuai pertimbangan lebih lanjut oleh perusahaan. Dalam hal ini ialah sistem Akuntansi biaya bisa menentukan harga-harga yang nantinya akan timbul karena adanya produk rusak.

Akuntansi biaya ialah sebuah proses penggolongan, penyajian dan pencatatan, dan penyajian biaya pembuatan dan penjualan produk jasa dengan cara tertentu sertabentuk penafsiran terhadapnya (Mulyadi, 2015). Akuntansi biaya informasi tentang biaya produksi untuk kepentingan kegiatan manajemen perusahaan industri, yang meliputi bahan baku, biaya tenaga kerja langsung, dan biaya overhead pabrik, penyimpanan, dan penjualan produk jadi (Sujarweni, 2015). Dengan adanya beberapa asumsi yang telah dijelaskan sebelumnya, maka perusahaan harus bisa menetapkan harga jual produk yang telah mengalami cacat (produk tidak sempurna seperti mengalami kecacatan fisik, kondisi penyok, 
Journal of Sustainability Business Research (JSBR)

Vol-1,Issue-1,Desember (JSBR)

E-ISSN: 2746-8607

http://jurnal.unipasby.ac.id/index.php/jsbr

ukuran tidak sesuai, produk mengalami kerosi), sehingga harga jualnya menjadi harga rata-rata yang berada di pasaran. Harga jual produk nantinya akan disesuaikan dengan proses produksi ulang dengan mempertimbangkan bop pabrik. Hal ini diharapkan bisa menjual produk dengan harga yang bersaing dipasaran untuk menaikkan volume penjualan produk yang telah ditawarkan perusahaan.

\section{RUMUSAN MASALAH}

Rumusan masalah penelitian ini tentang bagaimana Pengaruh Perlakuan Akuntansi Produk Rusak dalam Perhitungan Harga Pokok Produksi di PT Jatim Taman Steel, MFG Sidoarjo?.

Adapun tujuan dari dilakukan nya penelitian ini yaitu untuk mengetahui pengaruh yang timbul dari

perlakuan akuntansi produk rusa ke dalam perhitungan HPP di PT Taman Jatim Steel, MFG Sidoarjo.

Referensi yang peneliti gunakan untuk melakukan penelitian ini ialah dari penelitian terdahulu,

:(1) Muhtarudin, M., \& Sulastri, T., 2019, Perlakuan Akuntansi Produk Rusak Dalam Menentukan Harga Pokok Produksi. (2) Noviana, 2017, Analisis Produk Rusak pada Perhitungan Harga Pokok Produksi. (3) Tabrani, 2017, Analisis Perlakuan Akuntansi Produk Rusak dalam Menghitung Harga Pokok Produksi.

Menurut Nur Nasution dalam penelitian Nosra Weti (2016) "kualitas produk ialah kecocokan penggunaan produk (fitness for use) untuk memenuhi kebutuhan dan kepuasan pelanggan."

Produk rusak merupakan sebuah barang jadi yang tidak memiliki kriteria standar mutu yang baik, yang secara ekonomis produk ini nantinya tidak lagi diperbaiki menjadi produk yang baik dan jika produk rusak melewati tahap produksi kembali, produk akan menyerap biaya bahan baku, biayatenaga kerja dan biaya overhead pabrik. (Mulyadi :2015).

Perlakuan harga pokok produk rusak menurut Harnanto, M (2017), Produk rusak, seperti halnya produk hilang, bisa terjadi pada tahap pengolahan manapun, meski pada umumnya tidak terdeteksi sampai dengan saat perhitungan/inspeksi fisik terhadap produk dilakukan."

\section{METODE}

Jenis penelitian yang dipilih untukmelakukan penelitian ini adalah jenis penelitian kuantitatif deskriptif. Populasi dan sampel dalam penelitian ini adalah laporan produk rusak PT Jatim Taman Steel, MFG Sidoarjo dengan pengambilan kriteria laporan produk rusak selama kurun waktu bulan Januari sampai Desember tahun 2018.Tujuan diambilnya kriteria sebagai berikut adalah untuk memfokuskan dan mempermudah penelitian yang diteliti oleh peneliti.Jenis data yang dipakai peneliti ialah data kuantitatif yang memiliki sifat deskriptif, dan peneliti menggunakan sumber data sekunder yaitu data laporan produk rusak yang dihasilkan selama periode 2018 awal-akhir.Teknik dalam menentukan kriteria sampel menggunaka teknik purposive sampling. Disini sampel diambil dari data produk rusak yang paling banyak didalam satu tahun periode tersebut. Dokumen yang digunakan adalah laporan tentang biaya untuk produksi, total 
Journal of Sustainability Business Research (JSBR)

Vol-1,Issue-1,Desember (JSBR)

\section{E-ISSN: 2746-8607}

http://jurnal.unipasby.ac.id/index.php/jsbr

penjualan, dan data produk rusak yang didapat dalam proses produksi produksi PT Taman Jatim Steel, MFG Sidoarjo selama periode Januari - Desember 2018. Dalam penelitian ini hanya memiliki satu variabel, hal ini memungkinkan peneliti lebih fokus untuk melakukan analisa yang dibutuhkan untuk melakukan riset lebih dalam terhadap hal yang ingin diteliti. Variabel yang digunakan peneliti adalah perlakuan akuntasi produk yang telah rusak dalam melakukan perhitungan harga pokok produksi untuk menghasilkan barang jadi/produk selesai , yang berpengaruh langsung terhadap HPP reparasi produk rusak.

Perlakuan akuntansi terhadap produk rusak dengan perhitungan harga pokok produksi besi baja adalah sebagai berikut :

1. Produk atau barang rusak yang dihasilkandari proses menghitung harga pokok produksi akan

dijadikan pengurang untuk hpp selesai. Produk rusak yang mampu terjual nantinya akan menjadi pengurang untuk harga pokok produksi baik, hal ini menyebabkan harga produksi yang telah selesai menjadi rendah dibanding dengan harga pokok produk sebelumnya, dikarenakan ada pengurangan dari harga penjualan barang atau produk yang telah rusak tersebut.

2. Hasil dari penjualan produk yang mengalami kerusakan akan dijadikan sebagaisalah satu biaya untuk mengurangi semua elemen biaya produksi yang akan hpp menjadi lebih kecil.

3. Hasil dari produk rusak nantinya juga akan diperlakukan sebagai pengurangan elemen biaya overhead pabrik. Dengan ini perlakuan yang diterima untuk hpp rusak hanya biaya overhead pabrik saja nantinya akan dikurangi dengan hasil produk yang akan dijual kembali.

Adapun peneliti menggunakan analisis data dengan pendekatan metode deskriptif yakni metode utuk menyusun, mengumpulkan lalu dilakukan analisis data untuk pemecahan masalah yang dihadapi dan meneliti berdasarkan teori yang berhubungan dengan penelitian (Sugiyono. 2017:312).

\section{HASIL}

Dalam hal ini produk rusak yang ada merupakan produk yang memiliki kualitas tidak baik dan juga produk ini tidak bisa dijual kembali. Perlakuan produk yang digunakan dalam proses perhitungan diawal memakai metode harga pokok rata-rata.

Perhitungan hpp (harga pokok produksi) yang telah sampai tahap akhir didapat dengan mengalikan jumlah produk akhir kategori baik dengan harga pokok per unit, lalu setelah itu mulai menambahkan hpp (harga pokok produk) rusak yang diperoleh dari jumlah produk rusak dikalikan dengan harga pokok per unit setelah itu akan melakukan penjumlahan harga pokok produk selesai yang baik dan harga pokok produk selesai yang rusak akan dijumlahkan dan dibagi dengan jumlah produk selesai yang baik maka akan diperoleh harga pokok perunit dengan membebankan harga pokok produk rusak pada produk selesai.

Perhitungan

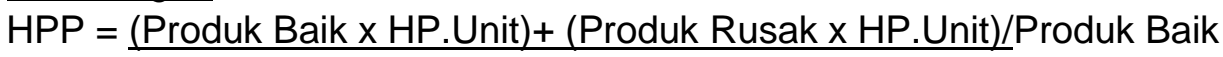

Perhitungan terakhir yang dilakukan ialah menambahkan hpp selesai dengan harga pokok produk dalam terakhir hal iniakan memperoleh besarnya harga pokok telah 
Journal of Sustainability Business Research (JSBR)

Vol-1,Issue-1,Desember (JSBR)

\section{E-ISSN: 2746-8607}

http://jurnal.unipasby.ac.id/index.php/jsbr

diperhitungkan.

Perhitungan

PDP akhir $\times$ HPP Bahan baku =

Rp..... PDP akhir x HPP Bahan baku

$$
=\operatorname{Rp} . . . .
$$

PDP akhir $\times$ HPP Bahan baku =

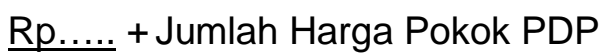

Akhir $=$ Rp.....

Berikut adalah laporan harga pokok produksi untuk item produk pada PT. Jatim Taman Steel,

Mfg.

Tabel 4.6

Perhitungan Harga Pokok Produk pada BILLET (2400-6000) SUP9A-LVS160_F4M

Perlakuan Akuntansi Produk Rusak di PT Jatim Taman Steel, MFG Sidoarjo.Jumlah total produksi BILLET (2400-6000) SUP9A-LVS160_F4M tahun 2018 selama tahun 2018 adalah 19.208 unit. Biayauntuk melakukan produksi disetiap satu unit billet adalah sebagai berikut :

HPP selesai baik: Rp.

4,228,427,686 HPP rusak:

Rp. 415,126,085

Biaya Bahan Baku Rp.1,339,500,000

Biaya Tenaga kerja langsung

Biaya Overhead Pabrik

$$
\text { Rp. 18,849,79 }
$$

Rp.37,952,500

HPP

$$
\text { Rp.6,039,856,066 }
$$

Hasil Produksi Baik 13,425

HPP Per unit Rp.449,896

Dibulatkan

$$
\text { Rp.450.000 }
$$

Pada perhitungan diatas diketahui biaya produksi untuk setiap unit billet untuk type (2400-6000) SUP9A-LVS160_F4M tahun 2018 ialah sebesarRp. 500.000.

Pada tabel 4.6 diatas dapat dijelaskan bahwa Produk Masuk Awal Proses sebesar 4.658 unit, produk masuk sebesar 14.550 unit. Pada perhitungan ini terdapat biaya beban yaitu biaya terhadap biaya tenaga kerja yang bekerja secara langsung, biaya pengadaan bahan baku, dan juga biaya over head pabrik.

Adapun hasil perhitungan HPP untuk 30 produk pada tahun 2018 adalah proses akhir untukperhitungan harga pokok produksi pada produk BILLET (2400-6000) SUP9ALVS160_F4M tahun 2018 diperoleh hasil harga pokok produksi sebesar Rp. 6.039.856.066 dengan hasil produk selesai baik sebesar 13.425 unit.

Harga pokok produk menjadi salah satu komponen untuk menentukan harga pokok untuk melakukan penjualan barang produksi. Harga pokok penjualan yang ditetapkan akan memiliki pengaruh besar untuk mendapatkan keuntungan oleh perusahaan. Besar keuntungan yang diperoleh oleh perusahaan secara tidak langsung juga mempengaruhi 
Journal of Sustainability Business Research (JSBR)

Vol-1,Issue-1,Desember (JSBR)

\section{E-ISSN: 2746-8607}

http://jurnal.unipasby.ac.id/index.php/jsbr

besar pajak yang akan dibayarkan perusahaan. Harga pokok produksi yang rusak tetap dihitung dan selanjutnya ditambahkan pada harga pokok produksi baik. Selanjutnya ditambahkan beban biaya meliputi biaya tenaga kerja langsung, biaya untuk bahan baku, biaya over head pabrik. Selanjutnya total hpp dibagi jumlah produk yang dihasilkan.

\section{SIMPULAN}

Menurut analisis penelitian yang telah didapat oleh peneliti dengan menggunakan analisis-analisis yang telah dilakukan tentang perlakuan akuntansi terhadap produk rusak makapeneliti bisa membuat simpulan bahwa perlakuan akuntansi produk rusak di PT Jatim Taman Steel, MFG Sidoarjo bertentangan dengan teori-teori yang ada sebelumnya.Disebabkan adanya laporan pada harga produk tersebut menjadi salah satu bagian dari laporan produksi, dan juga terdapat pada laporan produk rusak yang terjadi tiap tahunnya, yang juga dimasukkan untuk dokumen produk akhir yang adaditiap tahun, menurut kajian teori yang ada, produk rusak tetap akan mendapat perlakuan sebagai produk rusak dan tidak termasuk laporan produk jadi (selesai).

\section{IMPLIKASI}

Implikasi dari hasil penelitian bagi perusahaan adalah sebaiknya perlakuan akuntansi untuk barang rusak harusnya disesuaikan dengan kajian teori yang ada, kemudian untuk penyajian laporan keuangan yang telah ada sebelumnya, harus ditempatkan dengan benar karena dengan adanya laporan keuangan tersebut dapat memperlihatkan gambaran mengenai proses produksi yang sebelumnya telah ada (feedback) dan sebaiknya pada tahap akhir perhitungan biaya produksi seharusnya dilakukan dilakukan pembulatan nilai agar hasil perhitungan yang diperoleh menjadi lebih akurat.

\section{KETERBATASAN PENELITIAN}

Keterbatasan dalam penelitian ini adalah perolehan data yang kurang maksimal karena pada PT Jatim Taman Steel hanya mengizinkan untuk melakukan pengambilan data dari data dokumen saja, selain itu peneliti mendapatkan periode yang singkat dalam melakukan penelitian ini, menyebabkan kurang tepatnya data atau informasi yang di dapat oleh peneliti.

\section{DAFTAR PUSTAKA}

Bastian dan Nurlela. 2014. Akuntansi Biaya : Kajian Teori dan Aplikasi. Edisi

Pertama. Graha Ilmu, Yogyakarta.

Harnanto. 2017. Akuntansi Biaya: Sistem Biaya Historis. Yogyakarta: BPFE.

Harnanto, M. 2017. Akuntansi Biaya : Konsep dan Metodologi Penggolongan Biaya, Elemen Biaya Produksi, Perhitungan Harga Pokok Produk. Yogyakarta: CV. Andi offset.

Hansen dan Mowen. 2016. Akuntansi Manajerial. Buku 2. Edisi 14. Jakarta :

Salemba Empat Homgren, Charles T. dkk. 2006. Akuntansi Biaya,

Penekanan Manajerial. Jakarta: PT. Indeks.

Muhtarudin dan Tuti Sulastri.(2019). Perlakuan Akuntansi Produk Rusak Dalam Menentukan Harga Pokok Produksi.http://journal.stiemb.ac.id/index.php/mea . Diakses tanggal 16 Agustus 2019, pukul 20:09 WIB.

Mulyadi. 2015. Akuntansi Biaya, Edisi 5. Yogyakarta: Sekolah Tinggi Ilmu Manajemen YKPN. 